\title{
Pemberian Ekstrak Daun Kemuning (Murraya paniculata (L.) Jack) dalam Air Minum terhadap Performa dan Kualitas Fisik Telur Puyuh Malon
}

\author{
The Effect of Additional Supplementation of Kemuning (Murraya paniculata (L.) Jack) Leaves Extract into Drinking Water \\ on Performance of Malon Quail Eggs \\ D M Suci', N U Nuha', Suryahadi ${ }^{1}$
}

Corresponding email:

dwi.margi2@gmail.com

1)Departemen Ilmu Nutrisi dan Teknologi Pakan, Fakultas

Peternakan, Institut Pertanian Bogor (Bogor Agricultural University/IPB University)

\section{ABSTRACT}

The aim of this study was to determine the effect of kemuning leaves (Murraya paniculata (L.) Jack) extract supplementation of the drinking water on performance and physical quality of egg. Twenty-four weeks old of malon hybrid quails which amounts to 240 birds were allocated in a Completely Randomized Design with four treatments and two replications. The treatments were namely P0 = control (without kemuning leaves extrct), and added kemuning leaves extract into drinking water ( 4 consecutive days per weeks) with dose of $3 \%(\mathrm{P} 1)$, $5 \%$ (P2) and 7\% (P3). The commercial diet used in this study contained $20.01 \%$ of crude protein. The results showed that supplementation of $3 \%$ and $7 \%$ of kemuning leaves extract into drinking water had no significant difference on performance and physical quality of egg. It was concluded that the dose of $5 \%$ kemuning leaf extract addition into total drinking water tends to produce the highest egg production (85\%).

Key words: Murraya paniculata (L.) Jack, performance malon quail, egg physical quality

\section{ABSTRAK}

Penelitian bertujuan melihat pengaruh ekstrak daun kemuning (Murraya paniculata (L.) Jack) yang ditambahkan ke dalam air minum terhadap performa dan kualitas fisik telur puyuh. Dua ratus empat puluh ekor puyuh malon betina berumur 24 minggu yang diberi ransum komersial mengandung protein kasar 20,01 \%. Rancangan acak lengkap dengan empat perlakuan dan dua ulangan digunakan dalam penelitian ini, perlakuan terdiri atas puyuh diberi air minum tanpa ekstrak daun kemuning (PO), dan puyuh diberi ekstrak daun kemuning dalam air minum (4 hari dalam seminggu) dengan dosis 3\% (P1), dosis 5\% (P2) dosis 7\% (P3) dari total air minum. Variabel yang diukur adalah performa (konsumsi ransum, produksi telur, bobot telur, konversi ransum, konsumsi air minum, dan mortalitas), dan kualitas fisik telur (indeks telur, persentase bobot kuning telur, persentase putih telur, skor warna kuning telur, persentase kerabang telur serta tebal kerabang telur). Hasil penelitian ini menunjukkan bahwa pemberian ekstrak daun kemuning dalam air minum dengan taraf 3\% hingga 7\% tidak mempengaruhi performa dan kualitas fisik telur. Kesimpulan hasil penelitian ini dosis pemberian ekstrak daun kemuning 5\% dari total air minum ekor-1 hari-1 cenderung menghasilkan produksi telur paling tinggi (85\%).

Kata kunci: kualitas fisik telur, Murraya paniculata (L.) Jack, performa puyuh 


\section{PENDAHULUAN}

Puyuh Jepang (Coturnix coturnix japonica) merupakan salah satu unggas yang menghasilkan telur yang memiliki kemampuan berproduksi cepat sekitar 41 hari mampu menghasilkan telur dan jumlah produksi telur setahun sekitar 250-300 butir telur pertahun. Sebagai penghasil bahan pangan bersumber protein hewani, telur puyuh sendiri memiliki harga yang relatif murah dan terjangkau oleh masyarakat. Puyuh Jepang tipe petelur (Coturnix japonica) disilangkan dengan puyuh Perancis tipe pedaging (Coturnix coturnix) menghasilkan turunan burung puyuh yang dinamakan malon. Persilangan ini bertujuan untuk menghindari terjadinya inbreeding dan meningkatkan performa produksi telur. Selain itu, ada beberapa faktor produksi yang mempengaruhi produktivitas dalam pemeliharaan burung puyuh yaitu salah satunya adalah pemberian feed additive yang ditujukan untuk mengoptimalkan produksi, diantaranya meningkatkan konsumsi ransum, membantu proses pencernaan dan absorpsi nutrien, membantu proses metabolis, pencegahan penyakit dan kesehatan ternak, serta memperbaiki kualitas produksi.

Kemuning (Murraya paniculata) merupakan pohon perdu, tumbuh liar di semak belukar ataupun dihutan termasuk famili Rutaceae (Nugroho et al. 2010). Daun kemuning mengandung banyak senyawa aktif diantaranya flavonoid (Nugroho et al. 2010; Adfa 2007). Komponen senyawa aktif tersebut berguna untuk menjaga kesegaran tubuh serta memperlancar peredaran darah (Zainuddin dan Wibawan 2007), sehingga daun kemuning dapat digunakan sebagai feed additive. Penggunaan ramuan herbal merupakan salah satu terobosan yang diharapkan mampu berfungsi sebagai salah satu feed additive dalam ransum unggas menggantikan peranan antibiotik. Ekstrak daun kemuning digunakan sebagai feed additive untuk memperoleh senyawa aktif berupa flavonoid dan steroid agar dapat dimanfaatkan oleh tubuh untuk meningkatkan produksi telur. Penelitian ini dilakukan untuk mengukur pengaruh ekstrak daun kemuning yang ditambahkan pada air minum terhadap performa dan kualitas fisik telur puyuh.

\section{METODE}

\section{Ternak dan Ransum}

Puyuh betina layer malon berumur 24 minggu berjumlah 240 ekor digunakan untuk penelitian ini. Pemeliharaan puyuh dilakukan selama 34 hari yang dibagi dalam 4 perlakuan dengan 2 ulangan, setiap ulangan terdapat 30 ekor.

Ransum yang digunakan adalah ransum puyuh layer komersial berbentuk crumble. Kandungan nutrien pada ransum puyuh layer dapat dilihat pada Tabel 1.
Tabel 1 Kandungan Nutrien Ransum Puyuh Layer

\begin{tabular}{lc}
\hline Nutrien & Kandungan Nutrien $^{1}$ \\
\hline Bahan kering (\%) & 93,23 \\
Protein kasar (\%) & 20,01 \\
Serat kasar (\%) & 6,18 \\
Lemak kasar (\%) & 7,53 \\
Abu (\%) & 9,19 \\
Kalsium (\%) & 3,54 \\
Pospor (\%) & 0,81 \\
Energi bruto (kkal kg-1) & 3703 \\
\hline 1Laboratorium Ilmu dan Teknologi Pakan, Fakultas Peternakan IPB
\end{tabular}

\section{Kandang dan Peralatan}

Kandang berbentuk baterai bertingkat digunakan dalam penelitian yang mempunyai 8 petak masing-masing petak berisi 30 ekor dilengkapi satu tempat ransum berada pada masing-masing sisi depan dan satu tempat air minum berada disamping. Kandang baterai menggunakan alas triplek dan dinding kawat.

\section{Pembuatan Ekstrak Daun Kemuning}

Daun kemuning yang memiliki warna hijau tua yang digunakan pada penelitian. Prosedur pembuatan ekstrak menggunakan metode juicing. Daun kemuning segar yang sudah dibersihkan dengan air, ditimbang sebanyak 20 gram. Kemudian daun dimasukkan ke dalam tabung jucier dan digiling sebanyak empat kali dengan ditambahkan $15 \mathrm{ml}$ air masing-masing tahap penggilingan. Ekstrak daun kemuning ditampung dalam wadah. Pemberian ekstrak kemuning dengan cara melarutkan ekstrak kemuning dalam air minum sesuai perlakuan dan ditambahkan gula merah sebanyak 5\% dari jumlah ekstrak yang dihasilkan seperti yang dilakukan Setyaningrum \& Siregar (2015).

\section{Pemeliharaan Ternak}

Puyuh dimasukkan secara acak ke dalam 8 kandang koloni bertingkat. Masing-masing kandang diisi dengan 30 ekor puyuh. Ransum yang diberikan sebanyak $30 \mathrm{~g}$ ekor $^{-1}$ hari $^{-1}$. Air minum juga diberikan pada puyuh setiap pagi sebanyak $80 \mathrm{ml} \mathrm{ekor}^{-1}$ hari-1 $^{-1}$. Sisa ransum dan air minum diukur setiap hari. Penambahan ekstrak kemuning dalam air minum dilakukan selama empat hari berturut-turut dan tiga hari setelahnya diberikan air minum tanpa penambahan ekstrak daun kemuning. Sebelum dilarutkan pada air minum, ekstrak daun kemuning diberi penambahan gula merah sebanyak 5\% dari ekstrak daun kemuning (Setyaningrum \& Siregar 2015). Penghitungan jumlah dan penimbangan bobot telur dilakukan setiap pagi setelah penimbangan sisa ransum dan air minum serta pemberian keduanya. Pengambilan sampel telur dilakukan sekali dalam seminggu. Telur diambil sebanyak 12 butir tiap ulangan kemudian diuji kualitas fisik telur. 


\section{Rancangan Percobaan dan Analisis Data}

Perlakuan yang diberikan pada penelitian ini adalah puyuh tanpa diberi ekstrak daun kemuning dalam air minum (PO) dan puyuh yang dberi ektrak daun kemuning dalam air minum dengan dosis 3\% (P1), 5\% (P2) dan 7\% (P3) dari 80 ml air minum puyuh ekor-1 hari-1.

Rancangan percobaan yang digunakan adalah Rancangan Acak Lengkap dengan empat perlakuan dan dua ulangan, setiap ulangan terdapat 30 ekor puyuh. Data yang diperoleh dianalisis dengan sidik ragam.

\section{Peubah yang Diamati}

Konsumsi Ransum. Konsumsi ransum diperoleh dengan menghitung jumlah pemberian ransum (g) yang dikurangi dengan jumlah sisa ransum (g) per ekor per harinya.

Produksi Telur (Quail Day Production). Produksi telur diperoleh dengan menghitung jumlah telur puyuh dan membaginya dengan jumlah puyuh yang ada dikalikan $100 \%$.

Konversi Ransum. Konversi ransum diperoleh dengan menghitung jumlah konsumsi ransum (g) per hari dibagi dengan jumlah bobot telur (g) per hari.

Rataan Bobot Telur. Rataan bobot telur diperoleh dengan menjumlahkan bobot telur (g) yang ada pada setiap kandang per ulangan lalu dibagi dengan jumlah puyuh (ekor) setiap kandang per ulangan, setelah itu dihitung rata-rata per harinya.

Konsumsi Air Minum. Konsumsi air minum diperoleh dengan mengukur jumlah air minum yang diberikan (ml) dengan sisa air minum ( $\mathrm{ml}$ ) per ekor per harinya.

Mortalitas. Mortalitas diperoleh dengan membagi jumlah sisa puyuh awal dengan jumlah puyuh akhir penelitian dikalikan $100 \%$.

Indeks Telur. Indeks telur diperoleh dengan membagi ukuran lebar telur dengan panjang telur.

Persentase Kuning Telur. Persentase kuning telur diperoleh dengan cara memisahkan kuning dan putih telur terlebih dahulu kemudian kuning telur ditimbang (g) dan dibagi dengan bobot telur (g) dan dikalikan $100 \%$.

Persentase Putih Telur. Mengurangi bobot telur dengan bobot kerabang dan bobot kuning telur (g) dibagi dengan bobot telur (g) dan dikalikan 100\%.

Persentase Kerabang. Persentase kerabang diperoleh dengan cara menimbang kerabang (g) dan membagi dengan bobot telur (g) dan dikalikan 100\%.

Tebal Kerabang. Tebal kerabang diperoleh dari hasil rataan pengukuran tebal kerabang $(\mathrm{mm})$ dengan menggunakan mikrometer sekrup.

Warna Kuning Telur. Warna kuning telur diperoleh dengan membandingkan warna kuning telur berdasarkan warna standar kuning telur dalam Roche Egg Yolk Colour Fan yang mempunyai kisaran nilai 1-15

\section{HASIL DAN PEMBAHASAN}

\section{Kandungan Zat Aktif Ekstrak Daun Kemuning}

Analisis fitokimia ekstrak daun kemuning (Tabel 2) menunjukkan bahwa ekstrak daun kemuning mengandung 3 (tiga) senyawa metabolik aktif yaitu phenolhidrokuinon, flavonoid dan steroid. Senyawa steroid merupakan senyawa aktif dengan konsentrasi tinggi pada ekstrak daun kemuning. Kandungan steroid dalam tanaman memiliki peranan hormonal karena diketahui steroid memiliki sifat estrogenik (Prajonggo et al. 1983). Efek estrogenik dapat meningkatkan produksi telur pada ayam (Subekti 2007). Flavonoid yang terkandung dalam jamu memiliki fungsi sebagai penghambat bakteri Escherecia coli untuk bakteri gram negatif dan Bacillus cereus untuk gram positif (Parubak 2013). Sifat antioksidan dari flavonoid berasal dari kemampuan untuk mentransfer sebuah elektron ke senyawa radikal bebas dan juga membentuk kompleks dengan logam. Kedua mekanisme itu membuat flavonoid memiliki beberapa efek, diantaranya menghambat peroksidasi lipid, menekan kerusakan jaringan oleh radikal bebas dan menghambat aktivitas beberapa enzim (Yuhernita \& Juniarti 2011).

\section{Performa Puyuh Layer Malon}

Pemberian ekstrak daun kemuning selain sebagai antioksidan diharapkan dapat digunakan untuk meningkatkan performa puyuh layer malon. Performa puyuh yang diberi ekstrak daun kemuning terdapat pada Tabel 3.

\section{Konsumsi Ransum}

Konsumsi ransum tidak dipengaruhi oleh senyawa aktif yang terdapat pada ekstrak kemuning dalam air minum puyuh. Menurut Iskender (2016) Flavonoid herbal dapat mengaktifkan mekanisme nafsu makan pada unggas dan berkontribusi untuk menyeimbangkan sistem mikroflora gastrointestinal. Pada Tabel 2 pemberian ekstrak daun kemuning yang diberikan melalui air minum selama 4 hari dalam seminggu tidak mempengaruhi konsumsi ransum. Pada penelitian ini

Tabel 2 Hasil Analisis Fitokimia Ekstrak Daun Kemuning

\begin{tabular}{ll}
\hline Jenis Fitokimia & Hasil $^{1}$ \\
\hline Alkaloid & - \\
Tanin & - \\
Phenolhidrokuinon & + \\
Flavonoid & ++ \\
Saponin & - \\
Steroid & +++ \\
Triterpenoid & - \\
\hline Keterangan : - = negatif; + = positif lemah; ++ = positif; +++ = positif \\
kuat (Parubak 2013) \\
1Laboratorium Analisis Kimia, Fakultas Matematika dan Ilmu \\
Pengetahuan Alam, IPB
\end{tabular}


Tabel 3 Performa Puyuh Layer Malon

\begin{tabular}{lrrrr}
\hline \multirow{2}{*}{ Peubah } & \multicolumn{4}{c}{ Perlakuan } \\
\cline { 2 - 5 } & P0 & P1 & P2 & P3 \\
\hline $\begin{array}{l}\text { Rataan } \\
\text { Konsumsi }\end{array}$ & $26,92 \pm 1,29$ & $26,30 \pm 1,54$ & $27,18 \pm 1,07$ & $27,25 \pm 1,54$ \\
$\begin{array}{l}\text { Ransum } \\
\left(\mathrm{g}^{-1} \text { ekor }^{-1} \text { hari }^{-1}\right) \\
\text { Quail Day } \\
\text { Production (\%) }\end{array}$ & & & & \\
$\begin{array}{l}\text { Rataan } \\
\text { Konversi }\end{array}$ & $2,22 \pm 0,14$ & $2,14 \pm 0,14$ & $2,26 \pm 0,12$ & $2,29 \pm 0,16$ \\
$\begin{array}{l}\text { Ransum } \\
\text { Rataan Bobot }\end{array}$ & $12,13 \pm 0,35$ & $12,32 \pm 0,27$ & $12,01 \pm 0,25$ & $11,94 \pm 0,34$ \\
Telur (g butir-1) & & & & \\
$\begin{array}{l}\text { Indeks Telur } \\
\text { Rataan }\end{array}$ & $0,77 \pm 0,01$ & $0,77 \pm 0,01$ & $0,78 \pm 0,02$ & $0,77 \pm 0,01$ \\
$\begin{array}{l}\text { Konsumsi Air } \\
\text { Minum (ml }\end{array}$ & $65,18 \pm 5,31$ & $65,96 \pm 7,22$ & $62,46 \pm 5,64$ & $57,58 \pm 8,37$ \\
ekor-1 hari-1) & & & & \\
Mortalitas (\%) & & & & \\
\hline
\end{tabular}

ada beberapa kemungkinan penyebabnya diantaranya dosis pemberian ekstrak daun kemuning masih belum optimal sehingga belum terlihat efek senyawa aktif terutama flavonoid terhadap peningkatan nafsu makan. Jenis dan jumlah senyawa aktif herbal dipengaruhi oleh cara pengolahan herbal (Halimah 2019).

Konsumsi ransum pada penelitian ini lebih tinggi dari Hilmi et al. (2015) dan Andari et al. (2018) yang menggunakan puyuh jepang (Coturnix coturnix japonica). Setiawan (2006) menjelaskan konsumsi ransum yang seimbang memberikan nutrien yang cukup bagi pertumbuhan dan produksi.

Kandungan zat aktif steroid yang paling tinggi terkandung dalam 7\% ekstrak daun kemuning tidak mempengaruhi produksi telur, tetapi dosis $5 \%$ cenderung meningkatkan produksi telur mencapai 85\% dibandingkan perlakuan lainnya (74-78\%). Namun penelitian ini memiliki produksi telur lebih tinggi daripada Siregar (2008) yaitu produksi telur puyuh Jepang umur 4 bulan periode produksi menggunakan tepung daun singkong dapat mencapai angka 72,38\%.

Efisiensi ransum cenderung paling tinggi diperoleh pada pemberian ekstrak daun kemuning sebanyak 3\% dibandingkan perlakuan lainnya (2,1 VS 2,2). Walaupun diperoleh produksi telur cenderung paling rendah (74\%). Nilai konversi pada penelitian ini lebih rendah daripada penelitian Siregar (2008) yaitu 3,57 yang menggunakan ransum komersial tetapi sama dengan hasil penelitian Hilmi et al. 2015 yang menggunakan piperine sebagai phytogenic feed additive.

\section{Rataan Bobot Telur}

Bobot telur merupakan salah satu tolok ukur yang penting bagi konsumen dan peternak, karena umumnya penjualan telur puyuh dalam satuan butir. Pemberian ekstrak daun kemuning dalam air minum tidak mempengaruhi rataan bobot telur. Rataan bobot telur
Tabel 4 Kualitas Fisik Telur Puyuh Layer Malon

\begin{tabular}{|c|c|c|c|c|}
\hline \multirow{2}{*}{ Peubah } & \multicolumn{4}{|c|}{ Perlakuan } \\
\hline & PO & P1 & P2 & P3 \\
\hline $\begin{array}{l}\text { Bobot Telur } \\
\text { sampel (g) }\end{array}$ & $12,13 \pm 0,35$ & $12,46 \pm 0,27$ & $12,09 \pm 0,25$ & $12,06 \pm 0,34$ \\
\hline \multicolumn{5}{|l|}{ Kuning Telur } \\
\hline (g) & $3,554 \pm 0,14$ & $3,734 \pm 0,09$ & $3,629 \pm 0,12$ & $3,59 \pm 0,11$ \\
\hline$(\%)$ & $29,30 \pm 1,05$ & $29,97 \pm 0,39$ & $29,99 \pm 0,94$ & $29,70 \pm 0,58$ \\
\hline \multicolumn{5}{|l|}{ Putih Telur } \\
\hline (g) & $7,40 \pm 0,17$ & $7,51 \pm 0,16$ & $7,33 \pm 0,11$ & $7,31 \pm 0,11$ \\
\hline$(\%)$ & $60,98 \pm 0,98$ & $60,24 \pm 0,56$ & $60,53 \pm 0,73$ & $60,62 \pm 0,37$ \\
\hline \multicolumn{5}{|l|}{ Kerabang } \\
\hline (g) & $1,17 \pm 0,02$ & $1,22 \pm 0,04$ & $1,14 \pm 0,05$ & $1,16 \pm 0,06$ \\
\hline (\%) & $9,72 \pm 0,15$ & $9,78 \pm 0,43$ & $9,48 \pm 0,44$ & $9,69 \pm 0,51$ \\
\hline \multicolumn{5}{|l|}{ Tebal } \\
\hline $\begin{array}{l}\text { Kerabang } \\
(\mathrm{mm})\end{array}$ & $0,23 \pm 0,01$ & $0,21 \pm 0,004$ & $0,20 \pm 0,01$ & $0,21 \pm 0,01$ \\
\hline
\end{tabular}

puyuh malon dalam penelitian ini memiliki bobot telur berkisar 11,94-12,32 g lebih besar dari bobot telur puyuh Jepang yang berkisar dari 9,036-10,34 g (Saerang et al. 2000; Hilmi et al. 2015). Puyuh yang digunakan merupakan jenis puyuh malon merupakan hasil persilangan puyuh Jepang dan puyuh Perancis. Hrnčár et al. (2014) menyatakan bahwa bobot telur dipengaruhi oleh tipe puyuh yaitu tipe pedaging menghasilkan bobot telur $(13,06 \mathrm{~g})$ lebih tinggi daripada tipe petelur $(11,48$ g). Kandungan zat aktif pada ekstrak daun kemuning tidak meningkatkan bobot telur.

\section{Indeks Telur}

Pemberian ekstrak daun kemuning dalam air minum pada puyuh layer Malon tidak mempengaruhi indeks telur. Penelitian ini memperoleh nilai indeks telur puyuh antara 77\%-78\%. Hasil ini sama dengan hasil indeks telur dari penelitian Zita et al. (2013), Yilmaz et al. (2011) dan Hanusova et al. (2016). Indeks telur biasanya digunakan untuk mengetahui bentuk telur yang baik sebagai syarat telur tetas.

\section{Konsumsi Air Minum}

Penelitian ini juga menunjukkan pemberian ekstrak daun kemuning 5\% dan $7 \%$ cenderung menurunkan konsumsi air minum (57-62 ml ekor-1 hari-1) dibandingkan kontrol (65 ml ekor-1 hari-1. Hal ini terjadi karena konsentrasi air minum yang semakin pekat sehingga berpengaruh terhadap respon palatabilitas puyuh. Konsumsi air minum hasil penelitian ini lebih rendah daripada konsumsi air minum puyuh yang diberi jamu rempah sekitar 70-84 ml ekor-1 hari-1 (Andari et al. 2018). Tanaman herbal memiliki bau yang khas dan rasa yang pedas, sehingga menurunkan palatabilitas dan berpengaruh terhadap menurunnya nafsu makan (Setyaningrum \& Siregar 2015).

\section{Mortalitas}

Mortalitas tertinggi dalam penelitian ini mencapai $10 \%$ pada perlakuan tanpa penambahan ekstrak daun 
kemuning (P0). Mortalitas terendah terjadi pada penambahan ekstrak daun kemuning dengan taraf $7 \%$ (P3) yaitu 1,67\%. Mortalitas pada taraf 3\% (P1) dan 5\% (P2) berurutan yaitu 5\% dan 6,67\%. Mortalitas pada puyuh umumnya terjadi diantaranya karena puyuh yang lemas terjepit kandang atau terinjak puyuh lain saat berkompetisi mengonsumsi ransum serta ada pula puyuh yang mati karena mengeluarkan telur yang terlalu besar.

\section{Kualitas Telur Puyuh Layer Malon}

Ekstrak daun kemuning memiliki senyawa aktif diharapkan dapat meningkatkan kualitas fisik telur puyuh layer malon yang terlihat pada Tabel 4 .

\section{Komposisi Fisik Telur}

Pemberian ekstrak daun kemuning dalam air minum pada puyuh layer malon tidak mempengaruhi kualitas fisik telur (persentase bobot kuning telur, persentase bobot putih telur, serta persentase bobot kerabang telur puyuh). Bobot dan persentase bobot kuning telur puyuh yang tidak berbeda pada penelitian ini disebabkan jenis pakan yang diberikan dan tingkat konsumsi ransum puyuh sama. Selain itu faktor strain, umur, dan kesehatan puyuh yang sama juga diduga menyebabkan bobot dan persentase bobot kuning telur tidak berbeda. Persentase putih telur lebih tinggi daripada persentase kuning telur (Song et al. 2000; Stojčić et al. 2012; Hrnčár et al. 2014; Hilmi et al. 2015) yaitu persentase putih telur berkisar $52 \%-63,52 \%$ dan persentase kuning telur 27\%-33\%.

Penelitian ini menghasilkan persentase bobot kerabang telur berkisar 9,48 \%-9,78 \% lebih rendah dari Hilmi et al. (2015) yaitu 14,85\% - 15,09 \% tetapi lebih tinggi dibandingkan Hrnčár et al. (2014) yaitu 8,88 \% pada petelur layer dan $8,89 \%$ pada puyuh pedaging. Song et al. (2000) menyatakan bahwa persentase kerabang telur puyuh mencapai 6,61\%- 7,99\%.

Tebal kerabang telur pada penelitian ini berkisar 0,20 $\mathrm{mm}-0,23 \mathrm{~mm}$, berbeda dengan hasil penelitian Song et al. (2000) dan Hilmi et al. (2015) yang menghasilkan tebal kerabang telur puyuh lebih rendah yaitu sebesar 0,174 mm. Ketebalan kerabang tidak nyata mempengaruhi daya tetas pada puyuh (Ergun \&Yamak 2017). Adanya perbedaan kandungan kalsium dalam ransum dan sumber kalsium meempengaruhi ketebalan kerabang (Sultana et al. 2007). Perbedaan penyerapan kalsium ke dalam tubuh yang digunakan sebagai pembentukan kerabang telur yang ada hubungannya dengan tingkat produksi telur dapat menghasilkan tebal kerabang yang berbeda dan pemberian ekstrak kemuning tidak mempengaruhi penyerapan kalsium dan nutrien lainnya. Hrncar et al. (2014) menyatakan bahwa genotipe bersama dengan nutrisi, kesehatan, usia, pemeliharaan, kondisi penyimpanan telur dan periode penyimpanan dapat mempengaruhi karakteristik kualitas telur.
Tabel 5 Persentase penyebaran skor warna kuning telur dari sampel yang diambil

\begin{tabular}{|c|c|c|c|c|c|}
\hline Yolk & \multicolumn{4}{|c|}{ Perlakuan } & \multirow[t]{2}{*}{ Rataan } \\
\hline $\begin{array}{l}\text { Colour } \\
\text { Fan }\end{array}$ & PO & P1 & P2 & P3 & \\
\hline 3 & 9,38 & 16,67 & 21,88 & 15,63 & 15,89 \\
\hline 4 & 54,17 & 55,21 & 52,08 & 43,75 & 51,30 \\
\hline 5 & 35,42 & 27,08 & 23,96 & 33,33 & 29,95 \\
\hline 6 & 1,042 & 1,042 & 2,08 & 7,29 & 2,87 \\
\hline
\end{tabular}

\section{Persentase Skor Warna Kuning Telur}

Skor warna kuning telur yang tinggi lebih disukai oleh konsumen, sehingga diperlukan nutrien yang dapat meningkatkan skor warna kuning telur. Pigmen yang berpengaruh terhadap warna kuning telur adalah pigmen karoten yang banyak terdapat pada hijauan. Setiap individu mempunyai kemampuan menyerap pigmen warna berbeda-beda sehingga terdapat skor penyebaran warna kuning telur dari sampel yang diukur (Tabel 5). Penyebaran skor warna kuning telur dari 3-6 pada setiap perlakuan dari jumlah sampel telur yang diambil. Persentase skor tertinggi terdapat pada skor 4 pada semua perlakuan dengan hasil rataan $51,3 \%$ dan persentase skor terendah pada skor 6 dengan hasil rataan 2,87\%. Skor warna kuning telur tidak dipengaruhi oleh karotinoid (betakaroten) yang ada pada ekstrak kemuning yang diberikan melalui air minum. Unggas yang mengkonsumsi pigmen karotenoid lebih tinggi akan menghasilkan intensitas warna kuning telur yang lebih tinggi. Warna kuning telur sangat dipengaruhi oleh bahan pakan yang digunakan dalam ransum khususnya jagung kuning. Hilmi et al. (2015) yang menggunakan jagung kuning sebanyak 58,40\% dalam ransum menghasilkan skor warna kuning telur sekitar 7-8.

\section{SIMPULAN}

Penambahan ekstrak daun kemuning dalam air minum puyuh layer malon dengan taraf 5\% cenderung meningkatkan produksi telur (85\%). Pemberian ekstrak kemuning pada taraf 3\% dalam air minum memiliki nilai efisiensi ransum paling tinggi. Penambahan ekstrak daun kemuning dalam air minum puyuh tidak mempengaruhi kualitas fisik telur puyuh.

\section{DAFTAR PUSTAKA}

Andari, A, Anisa EN, Wulandari RF \& Suci DM. 2018. Efek suplementasi jamu rempah pada puyuh (Coturnix coturnix japonica) terhadap performa dan kadar kolesterol telur. Jurnal Ilmu Nutrisi dan Teknologi Pakan 16 (2): 34-41

Adfa, M.2007. Isolasi senyawa flavonoid aktif berkhasiat sitotoksik dari daun kemuning (Murraya paniculata L.Jack). Jurnal Gradien 3(2): 262-266

Halimah, H, Suci, DM \&Wijayanti I.2019. Studi potensi penggunaan daun mengkudu (Morinda citrifolia L.) sebagi bahan antibakteri 
Escherichia coli dan Salmonella typhimurium. Jurnal Ilmu Pertanian Indonesia 24 (1): 56-64

Hanusova E, Hrnčár C, Hanus A, \& Oravcová M. 2016. Egg traits in Japanese quail. Acta Fytotechnica et Zootechnica 19 (Special Issue) : 62-67

Hilmi,M, Sumiati \& Astuti DA. 2015. Egg production and physical quality in Coturnix-coturnix Japonica fed diet containing piperine as phytogenic feed additive. Media Peternakan 38 (3): 150-155

Hrnčár C, Hanusová E, Hanus A \& Bujko J. 2014. Effect of genotype on egg quality characteristic of Japanese quail (Coturnix Japonica). Slovak Journal of Animal Science 47(1): 6-11.

Iskender H, Yenice G, Dokumacioglu E, Kaynar O, Hayirli A, \& Kaya A. 2016. The effect of dietary flavonoid supplementation on the antioxidant status of laying hens. Brazilian Journal of Poultry Science. 18 (4): 663-668

Nowaczewski S, Kontecka H, Rosiñski A, \& Koronowsk SBP. 2010. Egg quality of Japanese quail depends on layer age and storage time. Folia biologica (Kraków) 58(3-4): 201-207

Nugroho, AE, Riyanto S, Sukari MA, Maeyama K. 2010. Efek senyawa flavonoid dari kemuning (Murraya paniculata [L.] Jack terhadap pelepasan histamin dari kultur sel mast. Majalah Obat Tradisional 15 (1): 34-40

Parubak A S, 2013. Senyawa flavonoid yang bersifat antibakteri dari Akway (Drimys becariana Gibbs). Chemistry Progress 6 (1): 34-37

Prajonggo TS, DjatmikoW \& Soemarno. 1983. Pengaruh Sauropus androgynus L. Merr terhadap gambaran hisotologi kelenjar susu mencit betina yang menyusui. Prosiding Kongres Nasional XI FSI. Jakarta (ID): Hlm 735-739.

Saerang LP, Josephine, Yuwanta T \& Nasroedin. 2000. Pengaruh minyak nabati dan lemak hewani dalam ransum puyuh petelur terhadap performa daya tetas, kadar kolesterol dan plasma darah. Buletin Peternakan 22(2):96-101

Setyaningrum S \& Siregar DJS. 2015. Efektivitas minuman herbal terhadap pertumbuhan puyuh. Surya Agritama. 4:1:109-117

Siregar B. 2008. Pengaruh penambahan tepung daun singkong (Manihot utilisima crantz) dalam pakan terhadap performans produksi telur puyuh (Cortunix-cortunix japonica) petelur. Jurnal Ilmiah Ilmu-Ilmu Peternakan 11(1):28-33.

Song KT, Choi SH, \& Oh HR. 2000. A comparison og egg quality of pheasant, chukar, quail, and guinea fowl. Asian Australasian Journal Animal Science 13 (70): 986-990

Stojčić MD, Milošević N, Perić L, Jajić I, \& Tolimir N. 2012. Egg Quality of Japanese quail in Serbia. Biotechnology in Animal Husbandry 28(3): 425-431

Subekti, S. 2007. Senyawa fitosterol dalam daun katuk (Sauropus androgynous L. Merr) dan pengaruhnya pada fungsi reproduksi puyuh. [disertasi]. Sekolah Pascasarjana: Institut Pertanian Bogor

Sultana F, Islam MS \& Howlider MAR. 2007. Effect of dietary Calcium sources and levels on egg production and egg shell quality of Japanese quail. International Journal of Poultry Science 6 (2): 131136

Zainuddin D \& Wibawan IWT. 2007. Biosekuriti dan Manajemen Penanganan Penyakit Ayam Lokal. Dwiyanto K, Prijono ST, editor. Bogor (ID): Pusat Penelitian Biologi LIPI.

Zita L, Ledvinka Z \& Klesalova L. 2013. The effect of the age of Japanese quails on certain egg quality traits and their relationships. Veterinarski Archive 83 (2) : 223-232.

Yilmaz, A, Tepeli C \& Çağlayan T. 2011. External and internal quality characteristics in Japanese quails of different plumage color lines. Journal of Food Agriculture and Environment 9 (2): 375-379

Yuhernita \& Juniarti. 2011. Analisis senyawa metabolit sekunder dari ekstrak methanol daun Surian yang berpotensi sebagai antioksidan. Makara Sains 15(1): 48-52 